\title{
КОМП'ЮТЕРНІ БАЗИ ДАНИХ ДОКАЗОВОЇ МЕДИЦИНИ ЯК ДЖЕРЕЛО СИСТЕМАТИЧНИХ ОГЛЯДІВ
}

Національний медичний університет імені О. О. Богомольця

Якісне та доступне інформаційне забезпечення $€$ необхідною передумовою розроблення ефективних технологій та програм в охороні здоров'я. В статті описано особливості представлення та пошуку систематичних оглядів у основних базах даних доказової медицини.

Ключові слова: доказова медицина, комп'ютерні бази даних, систематичні огляди.

\section{КОМПЬЮТЕРНЫЕ БАЗЫ ДАННЫХ ДОКАЗАТЕЛЬНОЙ МЕДИЦИНЫ КАК ИСТОЧНИК СИСТЕМАТИЧЕСКИХ ОБЗОРОВ}

\begin{abstract}
Национальный медицинский университет имени А. А. Богомольца
Качественное и доступное информационное обеспечение является необходимым условием разработки эффективных технологий и программ в здравоохранении. В статье приведены особенности представления и поиска систематических обзоров в основних компьютерных базах данных доказательной медицины.
\end{abstract}

Ключевые слова: доказательная медицина, компьютерные базы данных, систематические обзоры.

\section{COMPUTER DATABASES OF EVIDENCE-BASED MEDICINE AS A SOURCE OF SYSTEMATIC REVIEWS}

O. H. Puzanova

\author{
National Medical University by 0.0 . Bohomolets
}

\begin{abstract}
Information support of high quality and availability is necessary to develop effective technologies and programs in health care. The article deals with the peculiarities of systematic reviews' presentation and searching in main computer databases of evidence-based medicine.
\end{abstract}

Key words: evidence-based medicine, computer databases, systematic reviews.

Вступ. Удосконалення методології та інформаційного забезпечення розробки технологій та програм профілактики в охороні здоров'я є актуальною медико-соціальною проблемою. Інформаційне забезпечення полягає в збиранні та обробленні інформації, потрібної для прийняття управлінських рішень. Згідно 3 принципами доказової медицини (ДМ) одного $з$ найважливіших світових досягнень останніх десятиліть - найбільш якісну таку інформацію містять систематичні огляди (CO; англ. systematic reviews), причому саме розроблені Кохрейнівським співробітництвом не підлягають критичному оцінюванню користувачів $[2,3,15,27]$. У 2008 р. ВООЗ визнала інформацію «системним елементом глобальної політики в охороні здоров'я», а пришвидшення організації СО дієвості та економічної прийнятності найбільш важливих заходів - «шляхом значного зміцнення бази наших знань», і відзначила прогрес у використанні таких оглядів управлінськими органами [28]. Саме пошук СО повинен бути першим етапом будь-якого наукового дослідження [2]. На сьогодні лише комп'ютерні бази ДМ представлено понад 200 сайтами. Аналіз літератури засвідчує опрацьованість методології пошуку доказів у Інтернет-ресурсах і доповнення його ручним пошуком у рецензованих медичних журналах, оцінювання джерел доказів згідно загальноприйнятих стандартів, а також розроблення клінічних керівництв і формулярних систем $[2,16]$. В Україні поширюється використання інформаційних продуктів 
ДМ, і саме таку форму науково-інформаційної діяльності вважають перспективною [1].

Мета роботи - характеристика основних комп'ютерних баз даних ДМ як джерела СО.

матеріали таметоди. Пошук СО проведено в Кохрейнівській бібліотеці (бази Cochrane Database of Systematic Reviews, DARE, HTA), Національній медичній бібліотеці США (Medline), комп'ютерних базах даних TRIP, EvidenceUpdates, Current Contents, Embase, AMED, BNI, CINAHL, LILACS, IndMed, Ovid HealthSTAR. Знайдені роботи розглядали як CO за зазначення цього в назві [16]. Використано системний підхід і метод експертних оцінок.

Результати та їх обговорення. Найбільш відомою метабазою даних ДМ є Кохрейнівська бібліотека (англ. Cochrane library), до складу якої входить низка баз даних високоякісних первинних і вторинних досліджень, у тому числі Cochrane database of Systematic Reviews, DARE, CENTRAL, HTA [27]. Діяльність Кохрейнівського співробітництва в світі визнано «еталоном роботи з високоякісною інформацією, що стосується ефективності охорони здоров'я». На сьогодні спільна праця 28 тис. людей з понад 100 країн допомагає розробникам галузевої політики «приймати зважені рішення з питань охорони здоров'я, основою яких є найкращі доступні зовнішні епідеміологічні докази, шляхом створення, оновлення та просування доступності кохрейнівських оглядів» $[5,15]$.

Кохрейнівська база даних CO (англ. Cochrane Database of Systematic Reviews) нараховує понад 4600 повнотекстових оглядів, присвячених важливим питанням охорони здоров'я [27]. Інтенсивність створення СО та звернення до них користувачів Інтернету невпинно зростає: лише з квітня 2010 р. по березень 2011 р. було розроблено 550 нових протоколів для таких оглядів, створено 389 і оновлено 449 СО. В 2010 р. повнотекстові СО завантажували 3957567 разів (на 14 \% більше, ніж у 2009 р.), а «топ-п'ятірку» їх - більше 40 тис. разів [5]. На сайті Кохрейнівської бібліотеки 50 найбільш рейтингових оглядів («топ50», англ. Top 50 Reviews) розміщують окремо, що дає можливість встановити, які теми викликали найбільший інтерес протягом останніх 24 годин, 7 днів, 30 днів і 3-х місяців [15], причому до «топ-50» не включають CO, абстракти яких наведено на www.thecochranelibrary.com. Частота звернень до найбільш рейтингових СО влітку 2012 р. втричі перевищила таку восени 2011 р.

Достатньо високою (10 \%) серед «топ-50» влітку 2012 р. виявилася частка СО, викладених ісnанською мовою, при тому восени 2011 р. таких у переліку не було взагалі. СО, розроблені китайськими дослідниками, представлені в Кохрейнівській бібліотеці в вигляді англомовних абстрактів [15]. Внесок останніх до діяльності Кохрейнівського співробітництва є надзвичайно важливим: Китайська національна база доказів (англ. Chinese Clinical Trial Database) містить понад 10 тис. первинних досліджень (2008 р.); щороку 1,5-2 тис. таких включають до реєстру CENTRAL; на основі їх створено понад 130 повнотекстових кохрейнівських СО і 75 протоколів (2006 p.). Понад 160 кохрейнівських СО присвячено дієвості традиційної китайської медицини (ТКМ). Швидкість збільшення числа розробників СО у країні принаймні в 10 разів перевищує аналогічний показник у Кохрейнівському співробітництві. Китай належить до 10 країн, що з 2004 р. зробили найбільш суттєвий внесок до Кохрейнівської групи оглядів (англ. Cochrane Review Group) [4].

До кохрейнівської підбази абстрактів оглядів дієвості DARE (англ. Database of Abstracts of Reviews of effectiveness) включають абстракти СО, опрацьованих Центром з оцінювання та поширення оглядів (англ. Centre for Review and Dissémination, CRD, York, UK) [30].

3 Кохрейнівської бібліотеки починають пошук доказів саме з питань дієвості втручань. Якщо запитання стосується етіологіі, чинників ризику, точності діагностичних і скринінгових тестів, прогностичних маркерів, то пошук відповіді зазвичай розпочинають у такій потужній базі ДМ, як Національна медична бібліотека США (англ. US National Library of Medicine, NLM) - Medline (вільний доступ через сервер PubMed [21]). Ресурс містить понад 15 млн. статей, відібраних з 5,5 тис. науково-медичних журналів, опублікованих більше, ніж у 70 країнах (на 40 мовах), але переважно в США. В цій базі представлено дані, отримані в період з 1966 р. і дотепер. Отримані в 1950-1965 рр. дані включено до «старого Medline», нові та ще не оброблені - до PreMedline. Pесурс PubMed було розроблено Національним центром біотехнологічної інформації (англ. National Center for Biotechnology Information, NCBI) при NLM. Ця база даних ДМ містить понад 22 млн. статей i абстрактів 3 клінічної медицини та охорони здоров'я, стоматології, сестринської практики та ветеринарії. PubMed забезпечує доступ і до тих статей у рецензованих журналах, які не було включено до Medline [20]. Понад 3 тис. робіт, представлених у PubMed, присвячено обгрунтуванню дієвості ТКМ [4].

Пошук CO в PubMed доцільно здійснювати за алгоритмом, наведеним на «PubMed Quick Start» (укр. 
«Швидкий старт PubMed»), або шляхом відбирання їх у секції «Clinical Queries» (укр. « Клінічні запитання»): 1) на домашній сторінці PubMed кликнути «Clinical Queries» чи провести розширений пошук у «More resources» (укр. «Більше ресурсів»); 2) ввести пошукові терміни (якими є компоненти структурованого запитання та зазвичай компоненти назви CO) та кликнути «Search» (укр. «Пошук») [21].

Пришвидшити пошук релевантних доказів у комп'ютерних базах ДМ дозволяють методологічні пошукові фільтри (МПФ), що враховують і пошукові терміни, і специфіку дизайну досліджень. Так, існують МПФ для СО, рандомізованих клінічних досліджень (РКД), обсерваційних, перехресних тощо [31].

Швидкий пошук СО (протягом декількох хвилин) зазвичай здійснюють у базах даних, створених видавничою групою Британського медичного журналу (англ. BMJ Publishing Group) та інформаційно-дослідницьким відділом \{англ. Health Information Research Unit) канадського університету МакМастер (Торонто) [16]. Раніше вони розробили ресурс bmjupdates [7], що представляв найкращі зовнішні докази, в тому числі кохрейнівські СО. Статті відбирали з понад 110 провідних медичних журналів, опрацьовуючи протягом року близько 50 тис. робіт за допомогою спеціальних фільтрів якості, аналогічних таким на Evidence-Based Medicine [8]. Релевантними та новими визнавали не більше $6 \%$ н них (близько 3 тис. статей за рік) [7]. Знаючи галузь і категорію пошуку, в bmjupdates можна було здійснювати і розширений пошук доказів [16].

В теперішній час цей ресурс замінено на EvidenceUpdates [12]. Первинне рецензування статей здійснює штат дослідників (англ. Information Scientists), потім принаймні 3 визнані в світі експерти-практичні лікарі систематизують відібрані роботи за клінічними категоріями. Ресурс передбачає визначення 3-х найбільш рейтингових протягом останніх 30 днів СО. Сайт EvidenceUpdates забезпечує доступ до оприлюднених доказів $з$ питань етіології, діагнозу, прогнозу, лікування та економічних аспектів медичних проблем. Він не містить результатів усіх досліджень, але використовує чіткі критерії визначення валідності робіт, які заслуговують на увагу клініцистів. Розробники сайту наполягають на необхідності усвідомлення користувачами обмеження ролі доказів, унікальності клінічних випадків і можливості розходження думок спеціалістів з досліджуваних питань [12]. Враховуючи постійне оновлення доказів, розробники EvidenceUpdates схвалюють незалежне оцінювання інформації читачами: пропонується оцінювати релевантність і новизну доказів в onlineрежимі, використовуючи інструмент MORE (від англ. M cMaster Online Rating of Evidence) [9]. Отже, особливостями EvidenceUpdates як ресурсу ДМ можна вважати представлення нещодавно оприлюднених CO (у тому числі кохрейнівських) і забезпечення доступу до найкращих доказів з питань практики в первинній ланці медичної допомоги, внутрішньої медицини та їі субспеціальностей.

Важливим комп'ютерним ресурсом ДМ є TRIP [25]. Вбудовані в ньому фільтри обмежують пошук науково-медичної інформації «великою четвіркою» рецензованих журналів - «British Medical Journal» (BMJ; www.bmj.com), "The Journal of the American Medical Association" (JAMA; jama.ama-assn.org), "Lancet» (www.thelancet.com) та "New England Journal of Medicine» (NEJM; www.nejm.org). Отже, поряд із Кохрейнівською бібліотекою, Medline та EvidenceUpdates, TRIP належить до «метабаз ДМ» - ресурсів інформації, що пройшла експертну оцінку. Пошук CO в TRIP i Medline визначено G.Healy як «пришвидшений» [16], характеристику його наведе но в таблиці 1.

Таблиця 1. Інформаційні ресурси для пришвидшеного пошуку СО

\begin{tabular}{|c|c|c|c|}
\hline База даних & Легкість доступу & Легкість пошуку СО & Достовірність знайденої інформації \\
\hline $\begin{array}{l}\text { TRIP } \\
\text { http ://tripdatabase.com/ind } \\
\text { ex.html }\end{array}$ & $\begin{array}{l}\text { Вільний скрізь у } \\
\text { світі }\end{array}$ & $\begin{array}{l}\text { Дуже легко. } \\
\text { Можна визначити } \\
\text { тип джерел доказів }\end{array}$ & $\begin{array}{l}\text { Висока. Включено лише СО, знайдені } \\
\text { в джерелах, які зазнали критичного } \\
\text { оцінювання }\end{array}$ \\
\hline $\begin{array}{l}\text { PubMed } \\
\text { (Clinical Queries) } \\
\text { http://www.ncbi.nlm.nih.g } \\
\text { ov/sites/entrez }\end{array}$ & $\begin{array}{l}\text { Вільний скрізь у } \\
\text { світі }\end{array}$ & $\begin{array}{l}\text { Використовуючи } \\
\text { пошук через Clinical } \\
\text { Queries, відокремити } \\
\text { CO достатньо легко }\end{array}$ & $\begin{array}{l}\text { Не всі статті, знайдені за допомогою } \\
\text { Clinical Queries, є CO, і вони } \\
\text { підлягають критичному оцінюванню }\end{array}$ \\
\hline
\end{tabular}

Станом на кінець вересня 2012 р. база даних TRIP містила 35318 джерел доказів, 3 них 27318 вторинних: 21895 CO, 2258 синопсів, решта - клінічні рекомендації (165 розроблених в Австралії і Новій Зеландії, 262 - в Канаді, 752 - у Великій Британії, 1956 - у
США, 30 - в інших країнах). Спеціальний фільтр «Clinical Area» (укр. «Клінічна галузь») дозволяс здійснювати пошук за 27 клінічними категоріями: «Кардіологія», «Акушерство і гінекологія», «Педіатрія», «Онкологія», «Гастроентерологія», «Інфекційні 
хвороби», «Хірургія», «Пульмонологія», «Психіатрія», «Неврологія», «Гематологія», «Ревматологія», «Ендокринологія», «Ортопедія», «Урологія», «Геріатрія», «Радіологія», «Анестезіологія», «Дерматологія», «Оториноларингологія», «Невідкладна допомога», «Фізіотерапія», «Первинна допомога», «Стоматологія», «Інтенсивна терапія», «Офтальмологія», «Алергологія та імунологія». Кожний документ, наявний у $T R I P$, віднесено до однієї чи декількох клінічних категорій: класифікація базується на ідентичності ключових слів, зазначених у назвах статей і в клінічних категоріях. Наприклад, дослідження питань раку передміхурової залози віднесено до категорій «Урологія» та «Онкологія», дослідження антигіпертензивної терапії в літніх осіб - до «Кардіології» та «Геріатрії». До категорії «Первинна допомога» статті відбирають за допомогою ручного пошуку, і через його повільність вона містить на сьогодні лише 627 робіт. Ресурс TRIP є доступним для перегляду на 7 мовах - англійській, уельській, іспанській, німецькій, французькій, італійській та португальській [26]. Перевагами цієї бази ДМ як джерела СО є легкість їхнього пошуку та висока достовірність знайденої інформації.

Надзвичайно ретельний пошук СО потрібний для створення клінічних рекомендацій, і на це витрачають ще більше часу - до 2-х годин з кожного запитання. Такий пошук здійснюють у базах даних ДМ, зазначених у таблиці 2 .

;и для розширеного пошуку СО

\begin{tabular}{|c|c|c|c|}
\hline Бази даних & Легкість доступу & Легкість пошуку СО & Достовірність знайденої інформації \\
\hline $\begin{array}{l}\text { EMBASE } \\
\text { та інші спеціальні } \\
\text { бази даних } \\
\text { (AMED, BNI, } \\
\text { CINAHL) }\end{array}$ & $\begin{array}{l}\text { Необхідно } \\
\text { підписатися та } \\
\text { перевіряти } \\
\text { можливість } \\
\text { доступу }\end{array}$ & $\begin{array}{l}\text { Важко. Ці бази даних } \\
\text { містять різні джерела } \\
\text { інформації. Для } \\
\text { знаходження СО необхідні } \\
\text { МПФ }\end{array}$ & $\begin{array}{l}\text { Недостатньо висока. } \\
\text { Не кожна робота, знайдена навіть } \\
\text { за допомогою МПФ, є СО. Знайдені } \\
\text { СО підлягають критичному } \\
\text { оцінюванню }\end{array}$ \\
\hline $\begin{array}{l}\text { LILACS, } \\
\text { IndMed }\end{array}$ & $\begin{array}{l}\text { Є вільним скрізь } \\
\text { у світі }\end{array}$ & $\begin{array}{l}\text { Не дуже легко. Необхідно } \\
\text { використовувати пошукові } \\
\text { терміни, що відповідають } \\
\text { назвам СО }\end{array}$ & $\begin{array}{l}\text { Недостатньо висока. Не кожна } \\
\text { робота, знайдена за допомогою } \\
\text { пошукових термінів, є СО. Знайдені } \\
\text { СО підлягають критичному } \\
\text { оцінюванню }\end{array}$ \\
\hline Тези конференцій & $\begin{array}{l}\text { Визначають } \\
\text { організатори } \\
\text { конференцій та } \\
\text { правила доступу } \\
\text { до веб-сайтів }\end{array}$ & $\begin{array}{l}\text { В деяких категорії доказів } \\
\text { відзначено, в інших для } \\
\text { відокремлення СО необхідні } \\
\text { пошукові терміни }\end{array}$ & $\begin{array}{l}\text { Залишається необхідним критичне } \\
\text { оцінювання знайдених СО, що } \\
\text { ускладнено відсутністю } \\
\text { повнотекстових документів }\end{array}$ \\
\hline $\begin{array}{l}\text { Google } \\
\text { http ://www. google. } \\
\text { com }\end{array}$ & $\begin{array}{l}\text { Є вільним скрізь } \\
\text { у світі }\end{array}$ & $\begin{array}{l}\text { Не дуже легко. Слід } \\
\text { використовувати пошукові } \\
\text { терміни, що відповідають } \\
\text { словам у назвах СО }\end{array}$ & $\begin{array}{l}\text { Необхідно усвідомлювати } \\
\text { небезпеку неякісної інформації }\end{array}$ \\
\hline
\end{tabular}

Базу даних $\boldsymbol{E} \boldsymbol{m} \boldsymbol{b a s e}$ присвячено переважно фармакології та клінічній медицині. Вона містить понад 24 млн. статей, відібраних з 7,6 тис. рецензованих журналів, які видають 31947 р. і дотепер. Embase містить усі роботи, включені до Medline, а також близько 5 млн. не включених до нього. Особливу увагу приділено дослідженням (у тому числі СО), присвяченим безпеці лікарських засобів, фармакоекономіці та правовим аспектам клінічних випробувань і лабораторних досліджень [18].

Корисною для роботи 3 якісною біомедичною інформацією є комп'ютерна база Current Contents / Clinical Medicine [13, 22], яку оновлюють щотижня, але для пошуку СО вона не є зручною. Також переважно через Ovid здійснюють доступ до $\boldsymbol{A M E D}$ унікальної бази даних з «Суміжних і комплементарних розділів медицини» (англ. Allied and Complemental
Medicine), розробленої в 19S5 р. інформаційною службою Британської бібліотеки (англ. Health Care Information Service) [14]. Можливий доступ до $A M E D$ через SilverPlatter [24]. Ресурс містить статті з 597 журналів, розділені за 3 -ма напрямами - парамедичні спеціальності, комплементарна медицина та паліативна допомога.

Доказовій практиці медичних сестер присвячено ресурси BNI та CINAHL. BNI (англ. British Nursing Index) містить статті 3 понад 200 англомовних спеціалізованих журналів, присвячених медсестринській i акушерській роботі, починаючи 3 19S5 p. [11]. CINAHL (англ. Cumulative Index to Nursing \& Allied Health) є спеціалізованою для медичних сестер і парамедиків базою даних, в якій індексують всі англомовні статті, а також публікації Американської асоціації медсестер (англ. American Nurses Association) i 
Національної ліги медсестер (англ. National League for Nursing) [19]. На сайті [17] висвітлено повні тексти 770 документів і 275 книг, присвячених питанням догляду за хворими, просвітницькій роботі з пацієнтами та їхній соціальній адаптації; проіндексовано понад 5 млн. спеціальних журналів; загалом опрацьовано понад 3,2 млн. статей, починаючи з 1937 р. Представлено понад 130 повнотекстових документів 3 доказової сестринської допомоги і близько 360 статей, присвячених дослідницькому інструментарію. На домашній сторінці CINAHL вторинні джерела доказів, у тому числі CO, зазначені в розділі «Document Types» (укр. «Типи документів») [17].

Вільним є також доступ до LILACS (iсп. Literatura Latino Americana em Ciencias da Saude) - бази даних доказів, отриманих у Латинській Америці та Карибському регіоні [6]. Вона містить статті з понад 600 журналів, видається англійською, іспанською та португальською. Зміст цього ресурсу (в тому числі CO) не відтворює жодна інша база даних ДМ. Метою створення ресурсу IndMed [10] було індексування 77 рецензованих медичних журналів, виданих в Індії, починаючи 31985 р. В рамках проекту «Національні бази даних індійських медичних журналів» було розроблено також ресурс medIND - портал повнотекстових статей, оприлюднених у медичних журналах в Індії та індексованих в IndMed чи PubMed. Знайдені в LILACS та IndMed CO підлягають критичному оцінюванню.

Оцінюванню різних аспектів технологій в охороні здоров'я присвячено такі інформаційні ресурси ДМ, як HTA та OvidHealthSTAR. Базу даних HTA (англ. Health Technology Assessment) [29] експерти Кохрейнівського співробітництва розробляють суміс-

\section{Лтература.}

1. А. Р. Уваренко Доказова медицина у спектрі наукової інформації та галузевої інноваційної політики / А. Р. Уваренко; ред. Л. Я. Ковальчук [та ін.] // Доказова медицина у спектрі наукової медичної інформації та інноваційної політики : матеріали наук.-практ. конф.-семінару. - Тернопіль: Укрмедкнига, 2005. - С.3-5.

2. Glasziou P. Evidence-based Medicine Workbook. Finding and applying the best evidence to improve patient care / $\mathrm{P}$. Glasziou, C. Del Mar - London: BMJ Books, 2003. - 132p.

3. Dopson, S. Knowledge to action?: evidence based health care in context / ed. by S. Dopson, L. Fitzgerald / New York: но з розташованим у Швеції міжнародним секретаріатом INAHTA. До неї включено дослідження, присвячені технологіям в охороні здоров'я, - і завершені, і такі, що тривають. Абстракти частіше мають розповідний, а не аналітичний характер, i не містять критичного оцінювання статей. Можливим є доступ з домашньої сторінки Кохрейнівського співробітництва [15]: кликнути about-us > evidence-based-health-care $>$ webliography $>$ books $>$ hta. Базу даних Ovid HealthSTAR [23] створено в 2000 р. на основі даних Medline. Ресурс присвячено організації охорони здоров'я та оцінці якості медичних технологій; він забезпечує доступ до журналів, книг і технічних доповідей, виданих у 1975-2002pp.

Висновки. 1. Доступ до СО високої методологічної якості є найбільш зручним у таких метабазах ДМ, як Кохрейнівська бібліотека (Cochrane database of Systematic Reviews) та TRIP, і використання цих джерел невпинно зростає.

2. Швидкий пошук СО доцільно проводити в базах даних TRIP i PubMed, а для розширеного також звертатись до тематичних (EMBASE, AMED, HTA, Ovid HealthSTAR, BNI, CINAHL) і національних ресурсів доказів (LILACS, IndMed тощо).

3. Представленню нових і оновлених СО присвячені такі комп'ютерні бази ДМ, як EvidenceUpdates та Current Contents / Clinical Medicine.

Перспективи подальших досліджень. Постійне опрацювання основних баз даних ДМ та використання СО дозволить вдосконалити методологію розроблення ефективних технологій і програм в охороні здоров'я України на засадах доказового підходу та світового досвіду.

Oxford University Press, 2005. - 223p.

4. Li, Y. Evidence-Based Medicine in China /Y. Li, X. Sun, L. Wang // Value in Health. - 2008. - Vol. 11 (Suppl. 1). - S.156158.

5. URL: http://annual-report.cochrane.org/content/our-plans

6. URL: http://bmj.com/rapid-response/2011/10/28/lilacsdatabase-useful-and-also-free

7. URL: http://ebn.bmj. com/content/8/2/39.full

8. URL: http://hiru.mcmaster.ca/ebmj/Ebmp p.htm

9. URL: http://hiru.mcmaster.ca/more/AboutMORE.htm 